\title{
Propagation of Sterile Ornamental Pepper by Cuttings and in Vitro Shoot-tip Culture
}

\author{
Fazal Sultanbawa ${ }^{1}$ and Sharad C. Phatak ${ }^{2}$ \\ Department of Horticulture, University of Georgia, Coastal Plain \\ Experiment Station, Tifton, GA 31793
}

Additional index words. nonflowering, Capsicum sp.

\begin{abstract}
A sterile (nonflowering) mutant pepper plant (Capsicum sp.) with large, purplish-green, leathery leaves and purplish-green stems was observed during a hybridization program for ornamental peppers. Propagation of this mutant was investigated using cuttings rooted in the greenhouse and in vitro cultures. The most suitable treatment for rooting of cuttings involved the use of two-node cuttings, 2 to $4 \mathrm{~mm}$ in diameter, treated with Rootone and rooted in Promix inside a humidity chamber kept in $60 \%$ shade. With this treatment, $40 \%$ of the cuttings had rooted after 8 weeks. Two-node shoot tips callused when cultured in vitro in Murashige and Skoog (MS) medium containing 4.9 or $9.8 \mu \mathrm{M}$ IBA or $8.8 \mu \mathrm{M}$ BA, but $60 \%$ had rooted after 8 weeks in half-strength MS medium without growth regulators. Chemical names used: $1 \mathrm{H}$-indole butyric acid (IBA), $N$-(phenylmethyl)-1 $H$-purin-6-amine (BA).
\end{abstract}

Several species of Capsicum have been cultivated extensively as vegetables and spices (Heiser, 1976). Selections from some species, such as $C$. annuum, have also been grown as ornamentals in view of their attractively colored fruits (Baggett and Kean, 1988). Capsicum spp. are commonly propagated by seed. However, under some circumstances, vegetative propagation becomes necessary, especially when plants are sterile, for plants having unique ornamental characters that segregate, and when it is difficult to obtain plants that express these characteristics by inbreeding.

During an extensive hybridization program for the improvement of variegated ornamental peppers, a single sterile (nonflowering) plant was observed. The leaves of this plant were leathery in texture and dark green with darkpurple patches on the abaxial surface. Leaf petioles were 1 to $2 \mathrm{~cm}$ long, and the leaf blades measured from 10 to $12 \mathrm{~cm} \times 3$ to 5 $\mathrm{cm}$. Young stems were purplish-green, while older parts were grayish-white.

Cuttings. Two-node cuttings, 2 to $4 \mathrm{~mm}$ in diameter and without leaves, were used for rooting in the greenhouse in Promix BX (1 horticultural sphagnum moss : 1 vermiculite : 1 perlite plus lime, superphosphate, calcium nitrate, fritted trace elements, and

Received for publication 25 May 1990. Supported by State and Hatch funds allocated to the Univ. of Georgia Agr. Expt. Stas. The cost of publishing this paper was defrayed in part by the payment of page charges. Under postal regulations, this paper therefore must be hereby marked advertisement solely to indicate this fact.

Graduate Student.

${ }^{2}$ Professor. wetting agent) (Premier Brands, New Rochelle, N.Y.). The effects of Rootone [0.067\% 1-naphthalene acetamide; $0.033 \%$ 2-methyl-1-naphthalene acetic acid; $0.057 \%$ 2-methyl-1-naphthalene acetamide, 1-H-indole butyric acid; $4 \%$ Thiram (tetramethyl thiuramdisulfide); and $95.83 \%$ inert material) (Amchem, Fremont, Calif.) and of a humidity chamber [transparent plastic food box $(21 \times 18 \times 35 \mathrm{~cm})$ with a snap-on lid] maintained in $60 \%$ shade were investigated. Controls consisted of rooting cuttings without Rootone and in uncovered containers exposed to greenhouse conditions and $60 \%$ shade. Fifteen cuttings were used in each treatment, with five cuttings per replicate. This whole experiment was repeated and results were combined for statistical analysis.

In vitro shoot-tip culture. Shoot tips, 2 to $3 \mathrm{~cm}$ long, were surface sterilized sequentially with $0.1 \%(\mathrm{w} / \mathrm{v}) \mathrm{HgCl}_{2}$ for $1 \mathrm{~min}, 0.5 \%$ $\mathrm{NaOCl}$ for $15 \mathrm{~min}, 70 \%$ ethanol for $30 \mathrm{sec}$, and then washed three times with sterile, distilled water. Shoot tips were cultured in 200$\mathrm{ml}$ Mason jars containing Murashige and Skoog medium (MS) (Murashige and Skoog, 1962) with 84 mm sucrose and 1\% agar (Difco Bacto). Treatments were 4.9 or $9.8 \mu \mathrm{M}$ IBA or $8.8 \mu \mathrm{M} \mathrm{BA}$ in half-strength MS medium with $84 \mathrm{~mm}$ sucrose and $1 \%$ agar. Cuttings were maintained under an 8 -h photoperigd with $40 \mu \mathrm{mol} \cdot \mathrm{m}^{-2} \cdot \mathrm{s}^{-1}$ from cool-white fluorescent 'light and at $25 \pm 3 \mathrm{C}$.

Highly humid conditions favored rooting cuttings in Promix (Table 1). Rootone promoted rooting only under high humidity inside the closed container, where rooting reached $40 \%$. Untreated cuttings under high humidity also rooted better than treated or untreated cuttings in open containers.
Table 1. Rooting percentage and statistical analysis of two-node cuttings of a sterile ornamental pepper after 8 weeks.

\begin{tabular}{|c|c|c|c|}
\hline $\begin{array}{c}\text { Rooting } \\
\text { environment }\end{array}$ & Rootone & \multicolumn{2}{|c|}{$\begin{array}{c}\text { Rooted cuttings } \\
(\%)\end{array}$} \\
\hline \multirow[t]{2}{*}{ Open containers } & \multicolumn{2}{|c|}{+} & 13.3 \\
\hline & \multicolumn{2}{|c|}{-} & 13.3 \\
\hline \multirow[t]{2}{*}{ Humidity chamber } & \multicolumn{2}{|c|}{+} & 40.0 \\
\hline & \multicolumn{2}{|c|}{-} & 23.3 \\
\hline Source & df & MS & F ratio \\
\hline Container (C) & $\overline{1}$ & $\overline{20.16}$ & $8.77^{* *}$ \\
\hline IBA & 1 & 4.16 & 1.81 \\
\hline $\mathrm{C} \times \mathrm{IBA}$ & 1 & 4.16 & 1.81 \\
\hline Error & 20 & 46.00 & -.. \\
\hline
\end{tabular}

** F ratio significant at $P=0.01$.

Shoot tips rooted in vitro rooted best $(60 \%$ at 8 weeks) in half-strength MS medium. Time for rooting varied from 4 to 8 weeks. Media that contained 4.9 or $9.8 \mu \mathrm{M}$ IB A induced callusing but not rooting. BA at 8.8 $\mu \mathrm{M}$ did not induce multiple shoot formation from shoot tips but did induce some callusing and swelling of shoot tips. Rooted shoots were successfully transferred to Promix 4 weeks after they had rooted. In the first week after transfer, plants were shaded and misted frequently; thereafter, they were maintained under greenhouse conditions at 28 to $30 \mathrm{C}$ and a 12-h photoperiod. This trial was repeated with similar results.

The higher rooting percentage of Rootonetreated cuttings inside humidity chambers suggests a positive interaction between humidity and growth regulators, but the difference in rooting between treated and untreated cuttings, though significant, was not high. However, the higher rooting in vitro in hormone-free medium suggested that humidity is more important for rooting of pepper cuttings than is treatment with growth regulators. Milbocker (1980) observed that high humidity maintained by mist propagation enhanced rooting of hard-to-root cuttings such as Eucalyptus spp.

Plants of various selections that rooted by use of the two best treatments reported above have been growing in the greenhouse for 20 months and have reached maturity.

\section{Literature Cited}

Baggett, J.R. and D. Kean. 1988. 'Marbles' and 'Riot' dwarf ornamental peppers. HortScience 23:1097.

Heiser, C.B., Jr. 1976. Peppers-Capsicum (Solanaceae), p. 265-268. In: N.W. Simmonds (ed.). Evolution of crop plants. Longmans, London.

Milbocker, D.C. 1980. High humidity propagation promotes healthy vigorous plant growth. Amer. Nurseryman 151(9):66-70.

Murashige, T. and F. Skoog. 1962. A revised medium for rapid growth and bioassays with tobacco tissue cultures. Physiol. Plant. 15:473497. 